\title{
Bioturbation has a limited effect on phosphorus burial in salt marsh sediments
}

\author{
Sebastiaan J. van de Velde ${ }^{1,2}$, Rebecca K. James ${ }^{3}$, Ine Callebaut ${ }^{4}$, Silvia Hidalgo-Martinez ${ }^{5}$, and \\ Filip J. R. Meysman ${ }^{5,6}$ \\ ${ }^{1}$ Bgeosys, Geoscience, Environment \& Society, Université Libre de Bruxelles, Brussels, Belgium \\ ${ }^{2}$ Operational Directorate Natural Environment, Royal Belgian Institute of Natural Sciences, Brussels, Belgium \\ ${ }^{3}$ Groningen Institute for Evolutionary Life Sciences, University of Groningen, Groningen, the Netherlands \\ ${ }^{4}$ Analytical, Environmental \& Geo-Chemistry, Vrije Universiteit Brussel, Brussels, Belgium \\ ${ }^{5}$ Department of Biology, Universiteit Antwerpen, Wilrijk, Belgium \\ ${ }^{6}$ Department of Biotechnology, Technical University of Delft, Delft, the Netherlands
}

Correspondence: Sebastiaan J. van de Velde (svandevelde@ naturalsciences.be) and Filip J. R. Meysman

(f.j.r.meysman@tudelft.nl)

Received: 15 September 2020 - Discussion started: 6 October 2020

Revised: 20 December 2020 - Accepted: 21 January 2021 - Published: 25 February 2021

\begin{abstract}
It has been hypothesized that the evolution of animals during the Ediacaran-Cambrian transition stimulated the burial of phosphorus in marine sediments. This assumption is centrally based on data compilations from marine sediments deposited under oxic and anoxic bottom waters. Since anoxia excludes the presence of infauna and sediment reworking, the observed differences in $\mathrm{P}$ burial are assumed to be driven by the presence of bioturbators. This reasoning however ignores the potentially confounding impact of bottom-water oxygenation on phosphorus burial. Here, our goal is to test the idea that bioturbation increases the burial of organic and inorganic phosphorus $\left(\mathrm{P}_{\text {org }}\right.$ and $\mathrm{P}_{\text {inorg }}$, respectively) while accounting for bottom-water oxygenation. We present solid-phase phosphorus speciation data from salt marsh ponds with and without bioturbation (Blakeney salt marsh, Norfolk, UK). In both cases, the pond sediments are exposed to oxygenated bottom waters, and so the only difference is the presence or absence of bioturbating macrofauna. Our data reveal that the rate of $\mathrm{P}_{\text {org }}$ and $\mathrm{P}_{\text {inorg }}$ burial are indistinguishable between bioturbated and non-bioturbated sediments. A large terrestrial fraction of organic matter and higher sedimentation velocity than generally found in marine sediments $\left(0.3 \pm 0.1 \mathrm{~cm} \mathrm{yr}^{-1}\right)$ may partially impact these results. However, the absence of a clear effect of bioturbation on total $\mathrm{P}$ burial puts into question the presumed importance of bioturbation for phosphorus burial.
\end{abstract}

\section{Introduction}

The evolution of animals near the Ediacaran-Cambrian transition ( $542 \mathrm{Myr}$ ago) was a major evolutionary event in Earth's history (Mangano and Buatois, 2017; Meysman et al., 2006; Wood et al., 2019). Early benthic animals developed the ability to burrow (the so-called "burrowing revolution"; Meysman et al., 2006), which profoundly changed the geochemical cycling and burial of elements in the seafloor (Aller, 1977; McIlroy and Logan, 1999; Meysman et al., 2006). Benthic fauna affect the seafloor in two separate ways: by the reworking of solid-phase particles (bio-mixing) and by the flushing of burrows (bio-irrigation), lumped together under the term "bioturbation" (Kristensen et al., 2012). Biomixing and bio-irrigation can have distinct effects on organic carbon mineralization and early diagenesis (Kostka et al., 2002; van de Velde and Meysman, 2016). For instance, bio-irrigation can promote aerobic respiration by flushing oxygenated bottom waters into deeper anoxic horizons (Archer and Devol, 1992; van de Velde and Meysman, 2016), whereas bio-mixing transports fresh organic from the sediment-water interface into the anoxic zone, thus stimulating anaerobic mineralization pathways (Berner and Westrich, 1985; van de Velde and Meysman, 2016).

Bioturbation has been proposed to play a key role in the sedimentary phosphorus (P) cycle. Via bio-mixing, bioturbating organisms transport $\mathrm{P}$ that is adsorbed on iron oxides 
from the oxic zone at the sediment surface into deeper sedimentary layers (Slomp et al., 1996). In the anoxic zone of the sediment, these iron oxides are reduced, and $\mathrm{P}$ is released further away from the sediment-water interface (SWI). Accordingly, $\mathrm{P}$ is retained longer in the sediment, which could stimulate the precipitation and eventual burial of inorganic $\mathrm{P}\left(\mathrm{P}_{\text {inorg }}\right)$ minerals, such as apatite (Slomp et al., 1996). Via bio-irrigation, benthic fauna can increase the availability of oxygen in the sediment (Volkenborn et al., 2019), which could stimulate the production of microbial polyphosphate compounds within the sediment column (Dale et al., 2016). Microbial polyphosphates are generated during the breakdown of organic matter under oxic conditions (Diaz et al., 2008) and can be converted into more refractory organic $P$ ( $\mathrm{P}_{\text {org }}$; as for example phosphate esters or phosphonates) or inorganic $\mathrm{P}$ minerals during diagenesis, which would then constitute a permanent $\mathrm{P}_{\text {org }}$ burial sink (Berner et al., 1993; Van Cappellen and Ingall, 1994; Diaz et al., 2008; Goldhammer et al., 2010; Ingall and Jahnke, 1997). Overall, bioturbation could increase the burial of organic and inorganic $\mathrm{P}$ in the sediment. Accordingly, it has been hypothesized that the rise of bioturbation at the Ediacaran-Cambrian boundary increased the burial of $\mathrm{P}$ in marine sediments (Boyle et al., 2014; Dale et al., 2016; van de Velde et al., 2018). Marine $\mathrm{P}$ burial plays a key role in the long-term functioning of the Earth system because $\mathrm{P}$ is considered the long-term limiting nutrient for marine primary productivity (Van Cappellen and Ingall, 1996). If more $\mathrm{P}$ becomes buried, photosynthesis would decrease, thereby limiting the overall burial of $\mathrm{C}_{\text {org }}$ in the seafloor, subsequently increasing atmospheric $\mathrm{CO}_{2}$ and lowering atmospheric $\mathrm{O}_{2}$ (Bergman et al., 2004; Berner, 1982). Hence, the rise of bioturbation may have increased atmospheric $\mathrm{CO}_{2}$ concentrations and decreased atmospheric $\mathrm{O}_{2}$ concentrations, thus inducing warmer climatic conditions and more widespread ocean anoxia (Boyle et al., 2014; van de Velde et al., 2018).

However, other factors play an important role for the burial of $\mathrm{P}$ in marine sediments. High sedimentation velocities stimulate the preservation of organic matter (Canfield, 1994), causing less mineralization of organic matter and consequently more burial of $\mathrm{P}_{\text {org }}$ associated with organic matter. Additionally, bottom-water redox conditions are important for P burial; sediments underlying oxic bottom waters generally show higher burial rates of $\mathrm{P}_{\text {org }}$ than sediments underlying anoxic bottom waters (Ingall and Jahnke, 1997; Ruttenberg, 2014; Slomp and Van Cappellen, 2007), as sediments underlying oxic bottom waters likely receive an extra source of $\mathrm{P}_{\text {org }}$ in the form of microbial polyphosphates (Diaz et al., 2008). It is difficult to disentangle the confounding effect or sediment accumulation, redox conditions and bioturbation because within the present-day seafloor, most sediments deposited under oxic conditions generally also experience bioturbation (Levin et al., 1991). As a result, the proposed effect of bioturbation on $\mathrm{P}$ burial has not been extensively verified under field or laboratory conditions.
To be able to adequately tease apart the impact of bioturbation from other confounding factors, one requires sites that have oxygenated waters and a similar input of organic matter but no bioturbation. While these conditions are extremely rare in the modern seafloor, they are found in salt marsh ponds along the North Sea coast of Norfolk (UK), which contain sediments with overlying oxygenated water that are either bioturbated or non-bioturbated (Antler et al., 2019; Hutchings et al., 2019). These two different sediment types can be found in neighbouring ponds, less than $5 \mathrm{~m}$ apart, and no systematic difference in local sediment input, organic matter supply or other boundary conditions has been found between the two pond types (Antler et al., 2019; Hutchings et al., 2019; van de Velde et al., 2020a). This remarkable biogeochemical dichotomy between the pond sediments has recently been attributed to alternative stable states, in which small initial differences between ponds are amplified through non-linear positive feedbacks in the sedimentary iron-sulfur cycle (van de Velde et al., 2020a).

Whatever the cause of the biogeochemical dichotomy, the important aspect here is that by comparing the geochemistry of the two oxygenated pond types, we can single out the effect of burrowing fauna on sediment biogeochemistry. These ponds within the Norfolk salt marsh complex, hence, provide a unique environment to study the impact of bioturbation on the burial of organic and inorganic phosphorus, without the confounding effect of bottom-water oxygenation. To this end, we collected solid-phase phosphorus data during three separate visits and quantified the burial rates of $\mathrm{P}$ in the bioturbated and non-bioturbated ponds.

\section{Materials and methods}

\subsection{Field site}

The Blakeney salt marsh (Fig. 1) is part of a larger salt marsh complex along the North Sea coast of East Anglia (UK). The higher, vegetated marsh hosts several shallow, water-filled ponds with a surface area of $\sim 50-500 \mathrm{~m}^{2}$ and a water depth of 10-20 cm (Fig. 1; van de Velde et al., 2020a). These ponds show a conspicuous dichotomy in terms of their sediment geochemistry and belong to either one of two end-member types. Pond sediments are either heavily bioturbated, and the solid phase is rich in iron oxides, or sediments are nonbioturbated, and the pore water is rich in hydrogen sulfide (Antler et al., 2019; Hutchings et al., 2019; van de Velde et al., 2020a). The bioturbated ponds are colonized by large macrofauna, mostly Nereis and Arenicola, at high densities ( $\sim 1000$ organisms $\mathrm{m}^{-2}$; Antler et al., 2019), while the nonbioturbated sediments do not show signs of macrofauna or burrows. Water column concentrations of oxygen, dissolved inorganic carbon (DIC) and nutrients are not statistically different between pond types, and both types of ponds have the same sedimentation flux $\left(0.9 \pm 0.1 \mathrm{~kg} \mathrm{~m}^{-2} \mathrm{yr}^{-1}\right)$, indicat- 


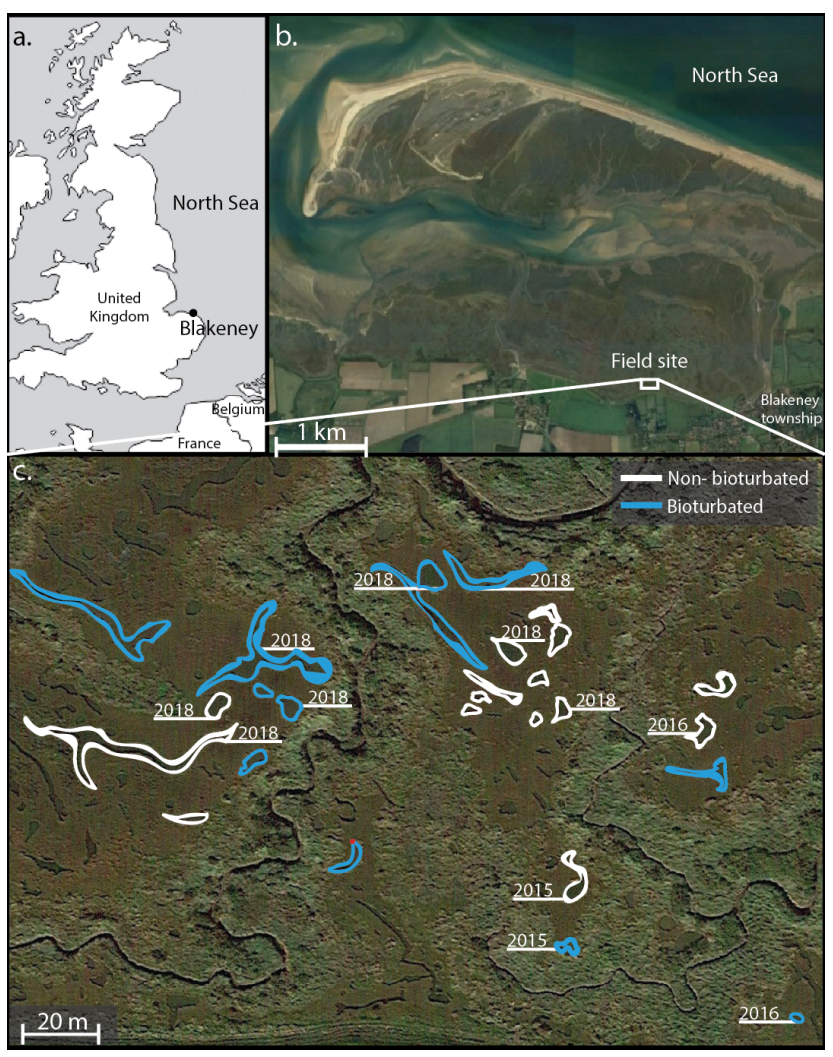

Figure 1. Overview of the field site in the Blakeney salt marsh system, UK. Sampled ponds are outlined in white (non-bioturbated) and blue (bioturbated), with ponds where sediment cores taken denoted with the sampling year. Coordinates of the sampled ponds are given in Table A1. (b, c) Map data (C) Google Maps 2020.

ing they receive a similar input of detrital minerals. Furthermore, all ponds display similar inputs of organic matter, thus suggesting that the only important difference between the ponds is the presence of burrowing fauna (van de Velde et al., 2020a). Depth profiles of ${ }^{137} \mathrm{Cs}$ show a well-defined peak in the non-bioturbated ponds, suggesting they have been undisturbed by fauna for at least 60 years (van de Velde et al., 2020a).

\subsection{Sediment sampling and analysis}

Sediment cores were collected on three separate visits (October 2015, August 2016 and August 2018). A total of 12 ponds were examined in total (sampling sites are indicated in Fig. 1). During each sampling campaign, two replicate sediment cores were collected from each sampled pond. Core sectioning was done at $0.5 \mathrm{~cm}$ resolution from 0 to $3 \mathrm{~cm}$ depth, at $1 \mathrm{~cm}$ resolution between 3 and $8 \mathrm{~cm}$ depth, and in $2 \mathrm{~cm}$ slices from 8 to $22 \mathrm{~cm}$ depth. Sediment $\mathrm{sec}-$ tions were collected in $50 \mathrm{~mL}$ centrifuge tubes (polypropylene; TPP Techno Plastic Products AG, Switzerland). In 2015 and 2016, sediment cores were processed under anaerobic conditions in a glove bag with $\mathrm{N}_{2}$, freeze-dried and stored in a sealed aluminium bag under $\mathrm{N}_{2}$ atmosphere for later solidphase analysis. In 2018, cores were immediately sliced in open air in the field and subsequently freeze-dried and stored under room conditions in $50 \mathrm{~mL}$ centrifuge tubes. This difference in sampling procedure reflects the subsequent analyses. In 2015 and 2016, the solid phase was analysed for different phosphorus fractions following the SEDEX (sequential extraction method) phosphorus extraction (Ruttenberg, 1992; Slomp et al., 1996). In 2018, due to the higher number of samples, we decided to use a simpler and faster extraction method that only differentiates between inorganic and organic phosphorus fractions (Bowman, 1989; Olsen and Sommers, 1982).

Sediment samples from all three campaigns were analysed for carbon and nitrogen content. To this end, freeze-dried solid-phase samples were ground to a fine powder and analysed by an Interscience Flash 2000 organic element analyser (precision $<5 \%$ ) for determination of particulate organic carbon (POC) and total nitrogen (TN). Before analysis, samples for POC were first acidified with $0.1 \mathrm{M} \mathrm{HCl}$ to remove the inorganic carbon (Nieuwenhuize et al., 1994). Concentrations of POC and TN are expressed as mass \% of dry sediment. Organic matter $\mathrm{C}_{\text {org }}: \mathrm{N}_{\text {tot }}$ was calculated as the molar ratio of POC over TN. The POC and TN results have been presented previously in van de Velde et al. (2020a).

The SEDEX procedure used in 2015 and 2016 separates total sedimentary $\mathrm{P}$ into five fractions: exchangeable $\mathrm{P}$ $\left(\mathrm{P}_{\text {exch }}\right), \mathrm{P}$ associated with iron $\left(\mathrm{P}_{\mathrm{Fe}}\right)$, authigenic $\mathrm{P}\left(\mathrm{P}_{\text {auth }}\right)$, detrital $\mathrm{P}\left(\mathrm{P}_{\text {det }}\right)$ and $\mathrm{P}$ associated with organic matter $\left(\mathrm{P}_{\text {org }}\right)$. All extractions were performed on a subsample of $300 \mathrm{mg}$, under room temperature and under constantly agitated conditions (the extraction procedure is detailed in Table A2). Inorganic phosphorus $\left(\mathrm{P}_{\text {inorg }}\right)$ is calculated as

$\mathrm{P}_{\text {inorg }}=\mathrm{P}_{\text {exch }}+\mathrm{P}_{\mathrm{Fe}}+\mathrm{P}_{\text {auth }}+\mathrm{P}_{\text {det }}$

and expressed as $\mu$ mol per gram dry sediment. The extraction procedure used in 2018 separates the sediment phosphorus content into two fractions: total phosphorus $\left(\mathrm{P}_{\text {tot }}\right)$ and inorganic phosphorus $\left(\mathrm{P}_{\text {inorg }}\right)$. Organic phosphorus is then calculated as the difference between $\mathrm{P}_{\text {tot }}$ and $\mathrm{P}_{\text {inorg }}$ (Bowman, 1989; Olsen and Sommers, 1982). Extractions were performed on a subsample of $1 \mathrm{~g}$, under room temperature and under constantly agitated conditions (extraction procedure detailed in Table A2).

\subsection{Burial fluxes and solid-phase inventories}

Burial fluxes of solid-phase species were calculated based on the sedimentation flux $\left(J_{\text {sed }}\right)$ and the concentration of the solid component at the bottom of the sediment column $\left(C_{\text {solid }}\right)$.

$J_{\text {burial }}=J_{\text {sed }} C_{\text {solid }}$ 
The sedimentation flux was previously determined based on ${ }^{210} \mathrm{~Pb}$ and ${ }^{137} \mathrm{Cs}$ dating and was statistically indistinguishable between pond types $\left(0.9 \pm 0.1 \mathrm{~kg} \mathrm{~m}^{-2} \mathrm{yr}^{-1}\right.$; van de Velde et al., 2020a).

Solid-phase inventories were calculated by integrating measured concentrations over the first $20 \mathrm{~cm}$ of the sediment cores:

$\mathrm{INV}=\rho_{\text {solidphase }} \int_{x_{\text {down }}}^{x_{\text {up }}}\left(1-\phi_{x}\right) \mathrm{C}_{\text {solid }} \mathrm{d} x$,

where $\phi_{x}$ is the porosity at depth $x$ and $\rho_{\text {solidphase }}$ is the solidphase density (previously determined to be $2.2 \mathrm{~g} \mathrm{~cm}^{-3}$; van de Velde et al., 2020a). The porosity depth profile was determined from the water content and solid-phase density, considering the salt content of the pore water. The water content of the sediment was determined as the difference in sediment weight before and after freeze-drying. Porosity profiles have been presented previously in van de Velde et al. (2020a).

\subsection{Statistics}

The measured values of $\mathrm{C}_{\text {org }}: \mathrm{N}_{\text {tot }}$ and $\mathrm{C}_{\mathrm{org}}: \mathrm{P}_{\text {org }}$, calculated burial fluxes of $\mathrm{P}_{\text {org }}$ and $\mathrm{P}_{\text {inorg }}$, and solid-phase inventories were averaged over the duplicate cores from each pond, and one-way ANOVA tests were used to test for significant differences between bioturbated and non-bioturbated ponds. Due to the different methods used for P extraction in 2015 and 2016 relative to 2018, the inclusion of the sampling year as a random effect was tested through model evaluation using AIC (Akaike information criterion). Sampling year was not significant for all dependent factors, and so it was excluded from subsequent analyses. Residuals were tested for normality and homoscedasticity, and all but $\mathrm{C}_{\text {org }}: \mathrm{P}_{\text {org }}$ fulfilled these assumptions. The values of $\mathrm{C}_{\mathrm{org}}: \mathrm{P}_{\text {org }}$ were $\log$-transformed before analysis.

\section{Results}

\subsection{Bioturbation and organic phosphorus burial}

Individual depth profiles of solid-phase variables (particulate organic carbon, POC; total nitrogen, TN; total phosphorus, TP; particulate organic phosphorus, POP; and particulate inorganic phosphorus, PIP) show variation within the sediments of a given pond type, indicating spatial heterogeneity (Fig. 2). Still, averaged depth profiles of the six non-bioturbated and the six bioturbated ponds reveal that non-bioturbated sediments have generally a stronger downcore gradient (Fig. 2a-j), which is expected as sediment bio-mixing by bioturbating fauna acts to erase solid-phase gradients (van de Velde and Meysman, 2016). Differences in POC, TN and POP inventories in the top $20 \mathrm{~cm}$ between bioturbated and non-bioturbated cores are insignificant (Fig. 2a, d, g, h; Table A4). Consistently, $\mathrm{C}_{\text {org }}: \mathrm{N}_{\text {tot }}$ and $\mathrm{C}_{\text {org }}: \mathrm{P}_{\text {org }}$ values are not significantly different between bioturbated and non-bioturbated pond types $(p>0.1$; Table A4). Values of $\mathrm{C}_{\text {org }}: \mathrm{N}_{\text {tot }}$ range from 9 to 15 , with an average value of 12 (Fig. $2 \mathrm{k}$ ). These values are slightly higher than expected for sediments from fully marine settings $\left(\mathrm{C}_{\text {org }}: \mathrm{N}_{\text {tot }}<10\right.$; Burdige, 2006) but are consistent with sediments from temperate salt marshes, which generally have $\mathrm{C}_{\text {org }}: \mathrm{N}_{\text {tot }}$ values of 10 or higher (Spivak et al., 2018). Similarly, $\mathrm{C}_{\text {org }}: \mathrm{P}_{\text {org }}$ values averaged around 500 in both the non-bioturbated and bioturbated sediment cores (Fig. 2g). These $\mathrm{C}_{\text {org }}: \mathrm{P}_{\text {org }}$ values are higher than expected for marine sediments with similar sedimentation rates underlying oxygenated waters $\left(\mathrm{C}_{\text {org }}: \mathrm{P}_{\text {org }}\right.$ of $\sim 200$; Slomp and Van Cappellen, 2007) and are more representative of low-oxygen and anoxic marine environments $\left(\mathrm{C}_{\mathrm{org}}: \mathrm{P}_{\mathrm{org}}=300-700\right.$; Slomp and Van Cappellen, 2007). However, since the pond waters were oxygenated at the time of sampling (van de Velde et al., $2020 a$ ), the elevated $C_{\text {org }}: P_{\text {org }}$ values most likely reflect the contribution of plant material from the surrounding marsh $\left(\mathrm{C}_{\text {org }}: \mathrm{P}_{\text {org }}>500\right.$; Table A3), which is substantially elevated above the $\mathrm{C}_{\text {org }}: \mathrm{P}_{\text {org }}$ of marine plankton $(\sim 106$; Redfield, 1934).

Overall, our organic $\mathrm{P}$ data show two main findings: (i) bioturbated sediments have similar amounts of $P_{\text {org }} \quad\left(P_{\text {inv }}=0.067 \pm 0.005 \mathrm{mmol} \mathrm{cm}^{-2}\right.$; Fig. 3a) compared with non-bioturbated sediments $\left(P_{\text {inv }}=0.072 \pm 0.004 \mathrm{mmol} \mathrm{cm}^{-2} ; \quad\right.$ Figs. 2, 3a), and (ii) differences in $\mathrm{P}_{\text {org }}$ burial in bioturbated sediments $\left(17 \pm 4 \mu \mathrm{mol} \mathrm{m}^{-2} \mathrm{~d}^{-1}\right)$ are not statistically significant from non-bioturbated sediments $\left(19 \pm 2 \mu \mathrm{mol} \mathrm{m}^{-2} \mathrm{~d}^{-1}\right)$ (Fig. 3b; $p>0.1$; Table A4).

\subsection{Bioturbation and inorganic phosphorus burial}

Our solid-phase analyses show that bioturbated sediments $\left(203 \pm 70 \mu \mathrm{mol} \mathrm{cm}{ }^{-2}\right)$ contain significantly more particulate inorganic phosphorus than non-bioturbated sediments $\left(113 \pm 17 \mu \mathrm{mol} \mathrm{cm}{ }^{-2}\right)(p<0.1$; Figs. $2 \mathrm{i}, \mathrm{j}, 3 \mathrm{a}$; Table A4)

SEDEX extractions, performed on sediment cores collected in 2015 and 2016, show that the large difference in $\mathrm{P}_{\text {inorg }}$ is caused by the much higher $\mathrm{P}_{\text {exch }}$ and $\mathrm{P}_{\mathrm{Fe}}$ contents in the bioturbated sediments (Fig. 4; $\mathrm{P}_{\text {exch }}+\mathrm{P}_{\mathrm{Fe}}$ is up to $90 \mathrm{mmol} \mathrm{P} \mathrm{cm}^{-2}$ higher in the bioturbated sediments; Table A5). Phosphorus adsorbed onto iron oxide minerals is transported from the sediment-water interface to the deeper sedimentary layers by the downward mixing of benthic fauna (Slomp et al., 1996). Indeed, $\sim 50 \%$ of the Fe minerals in the bioturbated sediments at the Blakeney salt marsh are in oxidized form, whereas $<10 \%$ are in the non-bioturbated sediments (see van de Velde et al., 2020a, for an extended discussion of the $\mathrm{Fe}-\mathrm{S}$ cycle at the field site).

The increased inventory of $\mathrm{P}_{\text {exch }}$ and $\mathrm{P}_{\mathrm{Fe}}$ at depth seemingly does not lead to more precipitation of $\mathrm{P}_{\text {auth }}$ (Table A5), since we do not find the detectable formation of authigenic apatite, the concentrations of which are neg- 


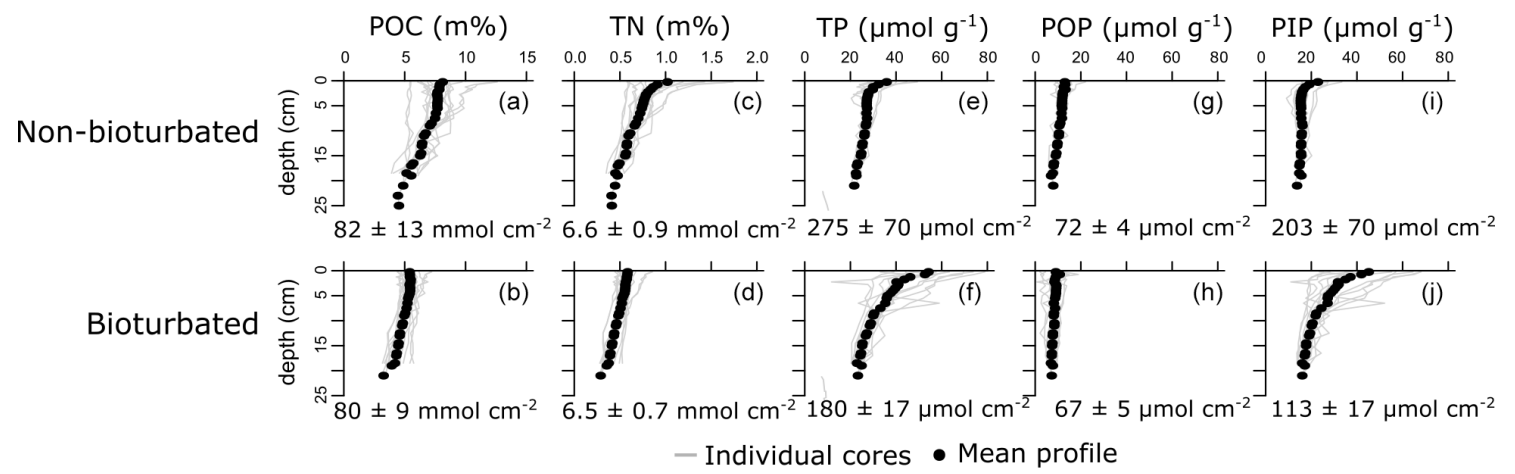

(k) Organic matter $\mathrm{C}: \mathrm{N}$ and $\mathrm{C}: \mathrm{P}$
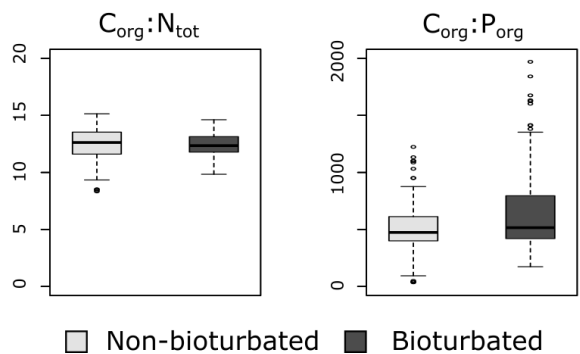

Figure 2. Vertical solid-phase profiles of (a, b) particulate organic carbon (POC), (c, d) total nitrogen (TN), (e, f) total phosphorus (TP), $(\mathbf{g}, \mathbf{h})$ particulate organic phosphorus (POP) and (i, j) particulate inorganic phosphorus (PIP). Individual cores are plotted as a light-grey lines, and the average vertical profile over all cores is plotted as black dots. Values are averaged inventories and errors are 1 standard deviation.

(k) Boxplots of the $\mathrm{C}_{\text {org }}: \mathrm{N}_{\text {tot }}$ and $\mathrm{C}_{\text {org }}: \mathrm{P}_{\text {org }}$ of the particulate organic matter fraction.

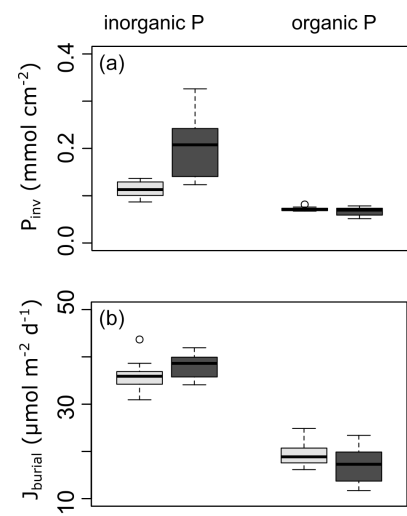

$\square$ Non-bioturbated $\square$ Bioturbated

Figure 3. Boxplots of (a) inventories and (b) burial rates of inorganic and organic P fractions. The data of 2015 are not included in (a), since some depth samples were not analysed for P fractionation.

ligible throughout all sediment cores in both ponds $(<$ $1 \mu \mathrm{mol} \mathrm{g}^{-1}$ ). While $\mathrm{P}_{\text {inorg }}$ concentrations are high in the top layers, they strongly decrease with depth; thus $\mathrm{P}_{\text {inorg }}$ is not efficiently buried. Overall, we find that the burial rate of $P_{\text {inorg }}$ is $38 \pm 3 \mu \mathrm{mol} \mathrm{m}^{-2} \mathrm{~d}^{-1}$ in bioturbated sediments and $36 \pm 3 \mu \mathrm{mol} \mathrm{m} \mathrm{m}^{-2} \mathrm{~d}^{-1}$ in the non-bioturbated sediment, and this difference is not significant ( $p>0.1$; Table A4).

\section{Discussion}

By comparing non-bioturbated and bioturbated sediment cores collected from an East Anglian salt marsh, this study provides a field verification for the hypothesis that bioturbation stimulates the burial of inorganic and organic $\mathrm{P}$ minerals. Our field data show that a bioturbated sediment contains more inorganic $\mathrm{P}$, which exists mainly in the form of ironassociated P. Nevertheless, the accumulation of inorganic $P$ occurs principally in the top layers of the sediment. At $20 \mathrm{~cm}$, the $P_{\text {inorg }}$ levels in bioturbated sediments decrease to similar levels as in non-bioturbated sediments (Fig. 4). We find no evidence for the formation of authigenic P (Fig. 4), which is at odds with previous hypotheses (Slomp et al., 1996; Zhao et al., 2020). Potentially, the high concentrations of $\mathrm{Fe}^{2+}$ in the pore water of the bioturbated sediments (up to $300 \mu \mathrm{M}$; van de Velde et al., 2020a) promoted the formation of vivianite over apatite (Ruttenberg, 2014). Because vivianite is extracted in the $\mathrm{P}_{\mathrm{Fe}}$ fraction (Nembrini et al., 1983), we cannot separate between $\mathrm{P}$ associated with iron oxides and $\mathrm{P}$ in the form of vivianite. The precipitation of vivianite in the bioturbated sediments could potentially stimulate the burial of $\mathrm{P}_{\text {inorg }}$, but this effect is not readily seen in our data. As a consequence, we find that the burial of $\mathrm{P}_{\text {inorg }}$ was not significantly different between bioturbated and non-bioturbated ponds, which does not support the idea that bioturbation stimulates the burial of inorganic P minerals. Our data are 


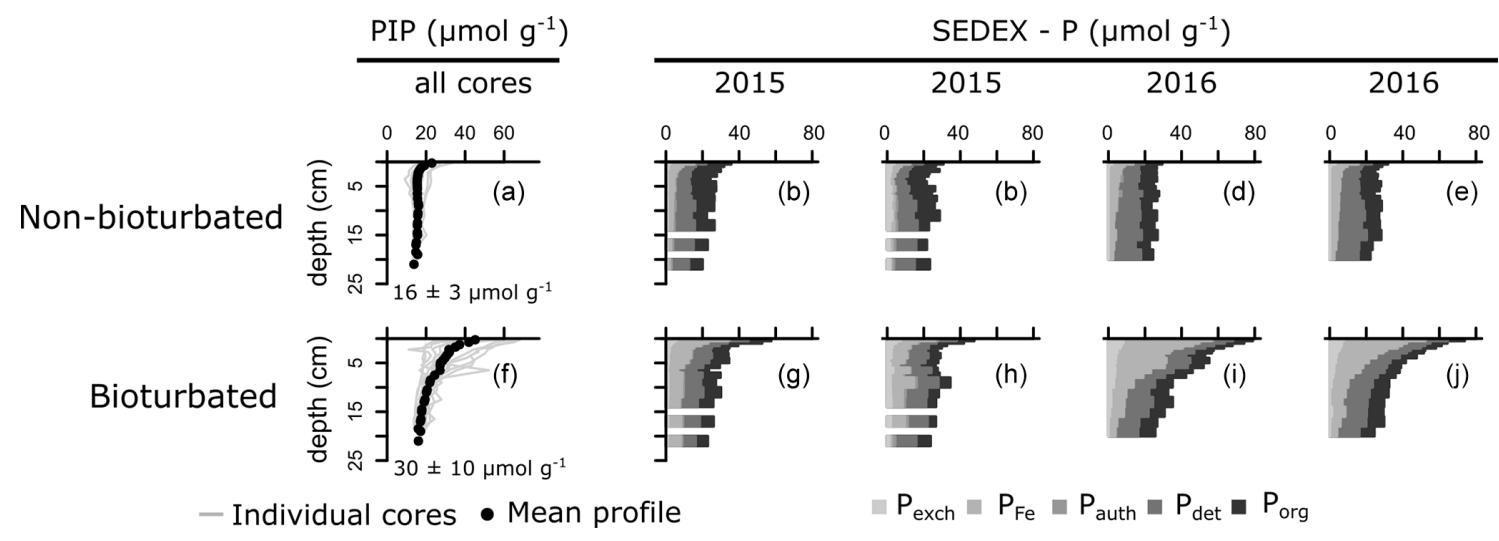

Figure 4. Vertical solid-phase profiles of non-bioturbated (a) and bioturbated (f) particulate inorganic phosphorus (PIP). Values are depthaveraged concentrations. (b-e, $\mathbf{g}-\mathbf{j}$ ) Solid-phase phosphorus speciation (SEDEX) of cores collected in 2015 and $2016 . \mathrm{P}_{\text {exch }}$ : exchangeable phosphorus, $\mathrm{P}_{\mathrm{Fe}}$ : iron-bound phosphorus, $\mathrm{P}_{\text {auth }}$ : authigenic phosphorus, $\mathrm{P}_{\text {det }}$ : detrital phosphorus, $\mathrm{P}_{\text {org }}$ : organic phosphorus. Note that the $\mathrm{P}_{\text {auth }}$ fraction is too small to be visible in the figure.

hence not congruent with previous modelling and field studies that have suggested that bioturbating fauna stimulates the burial of authigenic apatite (Slomp et al., 1996; Zhao et al., 2020). These studies argued that bioturbators mix iron oxides, on which phosphate is adsorbed, further away from the sediment-water interface (SWI), increasing the retention time of phosphate in the sediment and subsequently stimulating the precipitation and eventual burial of inorganic phosphorus minerals (Slomp et al., 1996; Dale et al., 2016). Bioturbators also flush their burrows however, which removes phosphate from the pore water (Dale et al., 2016). Consequently, depending on the animal community (irrigation versus mixing), the pore water can become undersaturated with respect to apatite, leading to lower precipitation rates and burial of apatite. The difference between oxic bioturbated and oxic non-bioturbated sediments inferred from the model study of Dale et al. (2016) is only a few $\mu \mathrm{mol} \mathrm{m}{ }^{-2} \mathrm{~d}^{-1}$, which is likely undetectable in a field study like ours (Fig. 3). Consequently, our results suggest that the effect of bioturbation on $\mathrm{P}_{\text {inorg }}$ minerals is small, consistent with diagenetic modelling results (Dale et al., 2016).

We find that the burial of $\mathrm{P}_{\text {org }}$ is indistinguishable between bioturbated and non-bioturbated sediments (Fig. 2g). Accordingly, our field data do not support the idea that bioturbation increases the burial of organic phosphorus. It should be noted however that the $\mathrm{C}: \mathrm{N}: \mathrm{P}$ ratios of the organic matter in the salt marsh pond sediments suggest a large contribution of plant material from the surrounding marsh (Fig. 2), which has elevated $\mathrm{C}: \mathrm{N}: \mathrm{P}$ ratios compared to marine organic matter (Table A3). Because terrestrial material is less easily degraded, the addition of plant material to the sediment organic matter pool dilutes the signal of the marine organic matter (Ruttenberg, 2014), which could explain why we see no effect of bioturbation. Another possible reason is that the sedimentation velocity in Norfolk salt marsh ponds is relatively high $\left(0.3 \mathrm{~cm} \mathrm{yr}^{-1}\right.$, compared to a mean value of $0.1 \mathrm{~cm} \mathrm{yr}^{-1}$ for shelf sediments; Burwicz et al., 2011). High sedimentation velocities stimulate the preservation of organic matter (Canfield, 1994) and would potentially further dilute the effect of bioturbation on $\mathrm{P}_{\text {org }}$ burial. Nevertheless, the POC profiles suggest an appreciable amount of organic matter is being degraded in the salt marsh pond sediments (Fig. 2). Indeed, organic matter mineralization rates based on POC and nutrient profiles range from 6 to $38 \mathrm{mmol} \mathrm{C} \mathrm{m}^{-2} \mathrm{~d}^{-1}$, which is comparable to rates observed in shallow marine sediments (Burdige, 2007) and thus indicates that the Blakeney salt marsh site shows a comparable metabolic activity to marine sediments. The observation then still remains; bioturbation seems to have no significant impact on $\mathrm{P}_{\text {org }}$ burial.

Bioturbation is believed to impact $\mathrm{P}_{\text {org }}$ burial by stimulating the formation of polyphosphates, which can act as an intermediate for the formation of apatite or more refractory organic P compounds (Berner et al., 1993; Goldhammer et al., 2010). Polyphosphates are formed during aerobic respiration of organic matter (Diaz et al., 2008), and because bio-irrigation stimulates aerobic respiration in the sediments (Archer and Devol, 1992; van de Velde and Meysman, 2016), it has been hypothesized that more polyphosphates could be formed in bioturbated sediments (Dale et al., 2016). However, other studies have shown that polyphosphates and the subsequent conversion to apatite also occur under anoxic conditions (Goldhammer et al., 2010), so it is questionable whether periodic influshing of oxygenated water would have a large impact on polyphosphate formation. Unfortunately, our analysis method does not allow us to differentiate between bulk organic $\mathrm{P}$ and microbial polyphosphates to investigate whether polyphosphate formation plays a role in both bioturbated and non-bioturbated sediments. This would be an interesting avenue for future research.

A number of caveats need to be taken into account when interpreting our results, as observations made in the surface sediments of the Norfolk salt marsh ponds are not necessarily 
representative of burial signals made several metres deep in coastal and shelf sediments. As noted above, the $\mathrm{C}_{\text {org }}: \mathrm{P}_{\text {org }}$ ratio of buried organic matter is high, as it is influenced by the deposition of the salt marsh vegetation with high C:P ratios, and therefore, caution is required when extrapolating our results to other coastal and shelf sediments. A difference in timescale is another caveat to take into account. Based on an average sedimentation velocity of $0.3 \mathrm{~cm} \mathrm{yr}^{-1}$ measured via radionuclide dating (van de Velde et al., 2020a), our samples represent only 60 years of sediment accumulation, and they hence indicate that, after $\sim 60$ years of early diagenesis, there is no discernible difference in burial of $\mathrm{P}$ minerals. Diagenesis later in the burial history could still affect longterm P burial. Data reported in the literature are collected from geological formations (see e.g. Ingall et al., 1993) or deep drill cores (see e.g. Slomp et al., 2004). These samples have undergone several hundreds to thousands of years of diagenesis before being sampled and analysed. However, we cannot see a mechanism via which bioturbation could have an imprint on the sediment that eventually leads to differential diagenesis of $\mathrm{P}$ minerals later in their burial history. If bioturbation does not already create a difference in $\mathrm{P}$ burial in the early phase of diagenesis, it is highly unlikely that will happen afterwards. So the difference in timescale cannot easily explain why $\mathrm{P}$ burial rates are similar in bioturbated and non-bioturbated sediments.

Overall, more field studies and laboratory experiments are required to verify our results. Nevertheless, the absence of a clear impact of bioturbation on $\mathrm{P}$ burial questions whether the modelled effects of the evolution of bioturbation in the early Cambrian, if they are solely based on inferred effects of bioturbation on $\mathrm{P}$ burial, do not overestimate the true impact of the burrowing revolution. Our study highlights that assumptions made in Earth system models should be firmly grounded in field observations, before accurate inferences about large-scale questions can be made, such as the impact of the burrowing revolution on the composition of the atmosphere and climate. 


\section{Appendix A}

Table A1. Coordinates and type of the ponds sampled in the 2015, 2016 and 2018 field campaigns in the Blakeney salt marsh. See Fig. 1c in the main text for relative geographical location of the ponds.

\begin{tabular}{lllr}
\hline & Coordinates & Type & Year sampled \\
\hline 1. & $52^{\circ} 57^{\prime} 22.7^{\prime \prime} \mathrm{N}, 01^{\circ} 00^{\prime} 14.0^{\prime \prime} \mathrm{E}$ & Bioturbated & 2015 \\
2. & $52^{\circ} 57^{\prime} 23.0^{\prime \prime} \mathrm{N}, 01^{\circ} 00^{\prime} 14.0^{\prime \prime} \mathrm{E}$ & Non-bioturbated & 2015 \\
3. & $52^{\circ} 57^{\prime} 22.2^{\prime \prime} \mathrm{N}, 01^{\circ} 00^{\prime} 16.6^{\prime \prime} \mathrm{E}$ & Bioturbated & 2016 \\
4. & $52^{\circ} 57^{\prime} 24.0^{\prime \prime} \mathrm{N}, 01^{\circ} 00^{\prime} 16.0^{\prime \prime} \mathrm{E}$ & Non-bioturbated & 2016 \\
5. & $52^{\circ} 57^{\prime} 25.2^{\prime \prime} \mathrm{N}, 01^{\circ} 00^{\prime} 13.2^{\prime \prime} \mathrm{E}$ & Bioturbated & 2018 \\
6. & $52^{\circ} 57^{\prime} 25.3^{\prime \prime} \mathrm{N}, 01^{\circ} 00^{\prime} 12.5^{\prime \prime} \mathrm{E}$ & Bioturbated & 2018 \\
7. & $52^{\circ} 57^{\prime} 24.6^{\prime \prime} \mathrm{N}, 01^{\circ} 00^{\prime} 10.6^{\prime \prime} \mathrm{E}$ & Bioturbated & 2018 \\
8. & $52^{\circ} 57^{\prime} 24.3^{\prime \prime} \mathrm{N}, 01^{\circ} 00^{\prime} 10.9^{\prime \prime} \mathrm{E}$ & Bioturbated & 2018 \\
9. & $52^{\circ} 57^{\prime} 24.7^{\prime \prime} \mathrm{N}, 01^{\circ} 00^{\prime} 13.4^{\prime \prime} \mathrm{E}$ & Non-bioturbated & 2018 \\
10. & $52^{\circ} 57^{\prime} 24.4^{\prime \prime} \mathrm{N}, 01^{\circ} 00^{\prime} 14.1^{\prime \prime} \mathrm{E}$ & Non-bioturbated & 2018 \\
11. & $52^{\circ} 57^{\prime} 24.3^{\prime \prime} \mathrm{N}, 01^{\circ} 00^{\prime} 9.9^{\prime \prime} \mathrm{E}$ & Non-bioturbated & 2018 \\
12. & $52^{\circ} 57^{\prime} 24.1^{\prime \prime} \mathrm{N}, 01^{\circ} 00^{\prime} 10.1^{\prime \prime} \mathrm{E}$ & Non-bioturbated & 2018 \\
\hline
\end{tabular}

Table A2. Specifics for the sequential extractions of phosphorus. After the extraction, the sample was centrifuged ( $2500 \mathrm{~g}$ for $10 \mathrm{~min})$, and the supernatant was filtered $(0.45 \mu \mathrm{m}$ cellulose acetate). ICP-OES: inductively coupled plasma optical emission spectrometry.

\begin{tabular}{|c|c|c|c|c|}
\hline Fraction & Extraction solution & Atmosphere & Time & Analysis \\
\hline \multicolumn{5}{|c|}{ SEDEX phosphorus extraction (Ruttenberg, 1992; Slomp et al., 1996) } \\
\hline$P_{\text {exch }}$ & $1 \mathrm{MMgCl}_{2}$ & $\mathrm{~N}_{2}$ & $30 \mathrm{~min}$ & Spectrophotometer \\
\hline \multirow[t]{2}{*}{$\mathrm{P}_{\mathrm{Fe}}$} & $\begin{array}{l}12 \mathrm{~g} \text { sodium dithionite in } 480 \mathrm{~mL} \text { sodium acetate }(1 \mathrm{M}) \\
+60 \mathrm{~mL} \text { sodium bicarbonate }(1 \mathrm{M})\end{array}$ & $\mathrm{N}_{2}$ & $8 \mathrm{~h}$ & ICP-OES \\
\hline & + wash: $1 \mathrm{M} \mathrm{MgCl}_{2}$ & $\mathrm{~N}_{2}$ & $30 \mathrm{~min}$ & Spectrophotometer \\
\hline \multirow[t]{2}{*}{$P_{\text {auth }}$} & $300 \mathrm{~mL}$ sodium acetate $(1 \mathrm{M})$ & Open air & $6 \mathrm{~h}$ & Spectrophotometer \\
\hline & $\begin{array}{l}+1700 \mathrm{~mL} \text { acetic acid }(1 \mathrm{M}) \\
\text { + wash: } 1 \mathrm{M} \mathrm{MgCl}_{2}\end{array}$ & Open air & $30 \mathrm{~min}$ & Spectrophotometer \\
\hline \multirow{2}{*}{$P_{\text {det }}$} & $1 \mathrm{~m} \mathrm{HCl}$ & Open air & $24 \mathrm{~h}$ & Spectrophotometer \\
\hline & + wash: $1 \mathrm{M} \mathrm{MgCl}_{2}$ & Open air & $30 \min$ & Spectrophotometer \\
\hline \multirow[t]{3}{*}{$\mathrm{P}_{\text {org }}$} & Combustion at $550^{\circ} \mathrm{C}$ & Open air & $2 \mathrm{~h}$ & \\
\hline & $1 \mathrm{MHCl}$ & Open air & $24 \mathrm{~h}$ & Spectrophotometer \\
\hline & + wash: $1 \mathrm{M} \mathrm{MgCl}_{2}$ & Open air & $30 \mathrm{~min}$ & Spectrophotometer \\
\hline \multicolumn{5}{|c|}{ One-step phosphorus extraction (Bowman, 1989; Olsen and Sommers, 1982) } \\
\hline$P_{\text {inorg }}$ & $1 \mathrm{M} \mathrm{H}_{2} \mathrm{SO}_{4}$ & Open air & Overnight & Spectrophotometer \\
\hline \multirow[t]{2}{*}{$\mathrm{P}_{\text {tot }}$} & Combustion at $550^{\circ} \mathrm{C}$ & Open air & $1 \mathrm{~h}$ & \\
\hline & $1 \mathrm{MH}_{2} \mathrm{SO}_{4}$ & Open air & Overnight & Spectrophotometer \\
\hline
\end{tabular}


Table A3. Summary of salt marsh plant properties. Data were first published in van de Velde et al. (2020a).

\begin{tabular}{lrrrrrrr}
\hline & \multicolumn{7}{c}{ Salt marsh properties } \\
\cline { 2 - 7 } & $\begin{array}{r}\text { Suaeda } \\
\text { maritima }\end{array}$ & $\begin{array}{r}\text { Salicornia } \\
\text { radicans }\end{array}$ & $\begin{array}{r}\text { Spartina } \\
\text { anglica }\end{array}$ & $\begin{array}{r}\text { Armeria } \\
\text { maritima }\end{array}$ & $\begin{array}{r}\text { Elytrigia } \\
\text { atherica }\end{array}$ & $\begin{array}{r}\text { Halimione } \\
\text { portulacoides }\end{array}$ & $\begin{array}{r}\text { Limonium } \\
\text { vulgare }\end{array}$ \\
\hline $\mathrm{C}_{\text {org }}: \mathrm{N}_{\text {tot }}$ & 18 & 20 & 27 & 20 & 74 & 26 & 25 \\
$\mathrm{C}_{\text {org }}: \mathrm{P}_{\text {org }}$ & 682 & 492 & 669 & 554 & 1289 & 802 & 692 \\
\hline
\end{tabular}

Table A4. Results from one-way ANOVA analysis and calculated $95 \%$ confidence intervals. Residuals were tested for normality and heterogeneity; all passed these assumptions except $\mathrm{C}$ : P, which was log-transformed. df: degrees of freedom.

\begin{tabular}{lrrrr}
\hline & \multicolumn{4}{c}{ One-way ANOVA } \\
\cline { 2 - 5 } & $\mathrm{P}_{\text {inorg }}$ burial rate & $\mathrm{P}_{\text {org }}$ burial rate & $\mathrm{C}_{\text {org }}: \mathrm{N}_{\text {tot }}$ & $\mathrm{C}_{\text {org }}: \mathrm{P}_{\text {org }}$ \\
\hline Pond type mean square (df) & $13.69(1)$ & $11.826(1)$ & $0.04417(1)$ & $0.0001(1)$ \\
Residual mean square (df) & $6.59(10)$ & $9.768(10)$ & $0.22665(10)$ & $0.07641(10)$ \\
$F$ value & 2.077 & 1.211 & 0.195 & 0.0 \\
$p$ & 0.18 & 0.297 & 0.668 & 0.991 \\
\hline Pond type & & $95 \%$ confidence intervals & \\
\hline Non-bioturbated & $33.65,38.32$ & $16.38,22.07$ & $11.52,12.39$ & $6.04,6.54$ \\
Bioturbated & $35.79,40.46$ & $14.40,20.08$ & $11.40,12.27$ & $6.04,6.54$ \\
\hline & $\mathrm{P}_{\text {inorg }}$ inventory & $\mathrm{P}_{\text {org }}$ inventory & POC inventory & $\mathrm{TN}$ inventory \\
\hline Pond type mean square (df) & $20006(1)$ & $1.05(1)$ & $28.61(1)$ & $0.0033(1)$ \\
Residual mean square (df) & $2847(10)$ & $75.8(8)$ & $132.14(10)$ & $0.6345(10)$ \\
$F$ value & 7.026 & 0.014 & 0.217 & 0.005 \\
$p$ & 0.029 & 0.91 & 0.652 & 0.944 \\
\hline Pond type & & $95 \%$ confidence intervals & \\
\hline Non-bioturbated & $58.26,168.31$ & $61.85,79.81$ & $72.40,93.31$ & $5.86,7.31$ \\
Bioturbated & $147.71,257.77$ & $61.20,79.16$ & $69.31,90.22$ & $5.82,7.27$ \\
\hline
\end{tabular}

Table A5. Inventories of the individual phosphorus fractions. $\mathrm{P}_{\text {org }}$ and $\mathrm{P}_{\text {inorg }}$ are reported as mean \pm 1 SD; SEDEX fractions are given as a range (due to the low number of replicates) from the 2016 cores (the 2015 cores were omitted because some depth samples were not analysed for $\mathrm{P}$ fractionation).

\begin{tabular}{lrrrrrr}
\hline & & \multicolumn{4}{c}{ Individual $\mathrm{P}_{\text {inorg }}$ fractions (only 2016) } \\
\cline { 4 - 7 } & $\mathrm{P}$ & $\mathrm{P}_{\text {org }}$ & $\mathrm{P}_{\text {inorg }}$ & $\mathrm{P}_{\mathrm{Fe}}$ & $\mathrm{P}_{\text {auth }}$ & $\mathrm{P}_{\text {det }}$ \\
\hline & $\mathrm{mmol}: \mathrm{cm}^{-2}$ & $\mathrm{mmol}: \mathrm{cm}^{-2}$ & $\mu \mathrm{mol}: \mathrm{cm}^{-2}$ & $\mu \mathrm{mol}: \mathrm{cm}^{-2}$ & $\mu \mathrm{mol}: \mathrm{cm}^{-2}$ & $\mu \mathrm{mol} \mathrm{cm}^{-2}$ \\
Non-bioturbated & $0.071 \pm 0.004$ & $0.11 \pm 0.02$ & $0.13-0.19$ & $30.1-32.2$ & $2.4-3.8$ & $100-103$ \\
Bioturbated & $0.067 \pm 0.009$ & $0.20 \pm 0.07$ & $10.1-17.3$ & $86.5-108$ & $2.2-2.8$ & $111-114$ \\
\hline
\end{tabular}


Data availability. All data presented in this paper are available from the VLIZ data repository (https://doi.org/10.14284/419, van de Velde et al., 2020b).

Author contributions. SJV conceived the hypothesis. SJvdV and FJRM organized the field sampling. All authors contributed to the field sampling. SJvdV and IC performed the SEDEX extractions. SJvdV analysed the data. RKJ did the statistical analyses. SJvdV and FJRM wrote the paper with input from all co-authors.

Competing interests. The authors declare that they have no conflict of interest.

Acknowledgements. The authors would like to thank Tom Van der Spriet from the University of Antwerp for the phosphorus extraction of the 2018 sediment samples.

Financial support. This research has been supported by the Fonds Wetenschappelijk Onderzoek (grant no. G038819N), the Universiteit Antwerpen (grant no. TOPBOF), the Netherlands Organisation for Scientific Research (grant no. 016.VICI.170.072) and the Belgian Federal Science Policy Office (grant no. FED-tWIN2019prf-008).

Review statement. This paper was edited by Marilaure Grégoire and reviewed by Peter Kraal and one anonymous referee.

\section{References}

Aller, R. C.: The influence of macrobenthos on chemical diagenesis of marine sediments, PhD thesis, Yale University, New Haven, Connecticut, 600 pp., 1977.

Antler, G., Mills, J. V., Huthings, A., Redeker, K., and Turchyn, A. V.: The sedimentary carbon-sulfur-iron interplay - a lesson from East Anglian salt marsh sediments, Front. Earth Sci., 7, 140, https://doi.org/10.3389/feart.2019.00140, 2019.

Archer, D. and Devol, A. H.: Benthic oxygen fluxes on the Washington shelf and slope: A comparison of in situ microelectrode and chamber flux measurements, Limnol. Oceanogr., 37, 614629, https://doi.org/10.4319/lo.1992.37.3.0614, 1992.

Bergman, N. M., Lenton, T. M., and Watson, A. J.: COPSE: A new model of biogeochemical cycling over phanerozoic time, Am. J. Sci., 304, 397-437, https://doi.org/10.2475/ajs.304.5.397, 2004.

Berner, R. A.: Burial of Organic Carbon and Pyrite sulfur in the modern ocean: Its geochemical and environmental sinificance, Am. J. Sci., 282, 451-473, 1982.

Berner, R. A. and Westrich, J. T.: Bioturbation and the early diagenesis of carbon and sulfur, Am. J. Sci., 285, 193-206, https://doi.org/10.2475/ajs.285.3.193, 1985

Berner, R. A., Ruttenberg, K. C., Ingall, E. D., and Rao, J.-L.: The Nature of Phosphorus Burial in Modern Marine Sediments, in: Interactions of $\mathrm{C}, \mathrm{N}, \mathrm{P}$ and $\mathrm{S}$ Biogeochemical Cycles and Global
Change, edited by: Wollast, R., Mackenzie, F. T., and Chou, L., Springer, Berlin and Heidelberg, Germany, 365-378, 1993.

Bowman, R. A.: A sequential extraction procedure with concentrated sulfuric acid and dilute base for soil organic phosphorus, Soil Sci. Soc. Am. J., 53, 362-366, https://doi.org/10.2136/sssaj1989.03615995005300020008x, 1989.

Boyle, R. A., Dahl, T. W., Dale, A. W., Zhu, M., Brasier, M. D., Canfield, D. E., and Lenton, T. M.: Stabilization of the coupled oxygen and phosphorus cycles by the evolution of bioturbation, Nat. Geosci., 7, 671-676, https://doi.org/10.1038/NGEO2213, 2014.

Burdige, D. J.: Geochemistry of Marine Sediments, Princeton University Press, Princeton, USA, 2006.

Burdige, D. J.: Preservation of Organic Matter in Marine Sediments: Controls, Mechanisms, and an Imbalance in Sediment Organic Carbon Budgets?, Chem. Rev., 107, 467-485, https://doi.org/10.1021/cr050347q, 2007.

Burwicz, E. B., Rüpke, L. H., and Wallmann, K.: Estimation of the global amount of submarine gas hydrates formed via microbial methane formation based on numerical reactiontransport modeling and a novel parameterization of Holocene sedimentation, Geochim. Cosmochim. Ac., 75, 4562-4576, https://doi.org/10.1016/j.gca.2011.05.029, 2011.

Canfield, D. E.: Factors influencing organic carbon preservation in marine sediments, Chem. Geol., 114, 315-329, 1994.

Dale, A. W., Boyle, R. A., Lenton, T. M., Ingall, E. D., and Wallmann, K.: A model for microbial phosphorus cycling in bioturbated marine sediments: Significance for phosphorus burial in the early Paleozoic, Geochim. Cosmochim. Ac., 189, 251-268, https://doi.org/10.1016/j.gca.2016.05.046, 2016.

Diaz, J., Ingall, E., Benitez-Nelson, C., Paterson, D., De Jonge, M. D., Mcnulty, I., and Brandes, J. A.: Marine Polyphosphate: A Key Player in Geologic Phosphorus Sequestration, Science, 320, 652-656, https://doi.org/10.1126/science.1151751, 2008.

Goldhammer, T., Brüchert, V., Ferdelman, T. G., and Zabel, M.: Microbial sequestration of phosphorus in anoxic upwelling sediments, Nat. Geosci., 3, 557-561, https://doi.org/10.1038/ngeo913, 2010.

Hutchings, A. M., Antler, G., Wilkening, J., Basu, A., Bradbury, H. J., Clegg, J. A., Gorka, M., Lin, C. Y., Mills, J. V., Pellerin, A., Redeker, K., Sun, X., and Turchyn, A. V.: Creek dynamics determine pond subsurface geochemical heterogeneity in East Anglian (UK) salt marshes, Front. Earth Sci., 7, 41, https://doi.org/10.3389/FEART.2019.00041, 2019.

Ingall, E. and Jahnke, R.: Influence of water-column anoxia on the elemental fractionation of carbon and phosphorus during sediment diagenesis, Mar. Geol., 139, 219-229, https://doi.org/10.1016/S0025-3227(96)00112-0, 1997.

Ingall, E. D., Bustin, R. M., and Van Cappellen, P.: Influence of water column anoxia on the burial and preservation of carbon and phosphorus in marine shales, Geochim. Cosmochim. Ac., 57, 303-316, 1993.

Kostka, J. E., Gribsholt, B., Petrie, E., Dalton, D., Skelton, H., and Kristensen, E.: The rates and pathways of carbon oxidation in bioturbated saltmarsh sediments, Limnol. Oceanogr., 47, 230 240, https://doi.org/10.4319/lo.2002.47.1.0230, 2002.

Kristensen, E., Penha-Lopes, G., Delefosse, M., Valdemarsen, T., Quintana, C. O., and Banta, G. T.: What is bioturbation? the need 
for a precise definition for fauna in aquatic sciences, Mar. Ecol. Prog. Ser., 446, 285-302, https://doi.org/10.3354/meps09506, 2012.

Levin, L. A., Huggett, C. L., and Wishner, K. F.: Control of deepsea benthic community structure by oxygen and organic-matter gradients in the eastern Pacific Ocean, J. Mar. Res., 49, 763-800, https://doi.org/10.1357/002224091784995756, 1991.

Mángano, G. M. and Buatois, L. A.: The Cambrian revolutions: Trace-fossil record, timing, links and geobiological impact, Earth-Science Rev., 173, 96-108, https://doi.org/10.1016/j.earscirev.2017.08.009, 2017.

McIlroy, D. and Logan, G. A.: The impact of bioturbation on infaunal ecology and evolution during the Proterozoic-Cambrian transition, Palaios, 14, 58-72, https://doi.org/10.2307/3515361, 1999.

Meysman, F. J. R., Middelburg, J. J., and Heip, C. H. R.: Bioturbation: a fresh look at Darwin's last idea., Trends Ecol. Evol., 21, 688-95, https://doi.org/10.1016/j.tree.2006.08.002, 2006.

Nembrini, G. P., Capobianco, J. A., Viel, M., and Williams, A. F.: A Mössbauer and chemical study of the formation of vivianite in sediments of Lago Maggiore (Italy), Geochim. Cosmochim. Ac., 47, 1459-1464, https://doi.org/10.1016/0016-7037(83)90304-6, 1983.

Nieuwenhuize, J., Maas, Y. E. M., and Middelburg, J. J.: Rapid analysis of organic carbon and nitrogen in particulate materials, Mar. Chem., 45, 217-224, 1994.

Olsen, S. R. and Sommers, L. E.: Phosphorus, in: Methods of Soil Analysis, Part 2, edited by: Page, A. L., Miller, R. H., and Keeney, D. R., American Society of Agronomy, Inc. Madison., American Society of Agronomy, Soil Science Society of America, Madison, USA, 403-430, 1982.

Redfield, A. C.: On the proportions of organic derivations in sea water and their relation to the composition of plankton, in: James Johnstone Memorial Volume, edited by: Daniel, R. J., University Press of Liverpool, Liverpool, UK, 177-192, 1934.

Ruttenberg, K. C.: Development of a sequential extraction method for different forms of phosphorus in marine sediments, Limnol. Oceanogr., 37, 1460-1482, 1992.

Ruttenberg, K. C.: The Global Phosphorus Cycle, 2nd Edn., Elsevier, 499-558, https://doi.org/10.1016/B978-0-08-0959757.00813-5, 2014.

Slomp, C. P. and Van Cappellen, P.: The global marine phosphorus cycle: sensitivity to oceanic circulation, Biogeosciences, 4, 155171, https://doi.org/10.5194/bg-4-155-2007, 2007.

Slomp, C. P., Epping, E. H. G., Helder, W., and Van Raaphorst, W.: A key role for iron-bound phosphorus in authigenic apatite formation in North Atlantic continental platform sediments, J. Mar. Res., 54, 1179-1205, 1996a.
Slomp, C. P., Thomson, J., and De Lange, G. J.: Controls on phosphorus regeneration and burial during formation of eastern Mediterranean sapropels, Mar. Geol., 203, 141-159, https://doi.org/10.1016/S0025-3227(03)00335-9, 2004.

Spivak, A. C., Gosselin, K. M., and Sylva, S. P.: Shallow ponds are biogeochemically distinct habitats in salt marsh ecosystems, Limnol. Oceanogr., 63, 1622-1642, https://doi.org/10.1002/lno.10797, 2018.

Van Cappellen, P. and Ingall, E. D.: Benthic phosphorus regeneration, net primary production, and ocean anoxia: A model of the coupled marine biogeochemical cycles of carbon and phosphorus, Paleoceanography, 9, 677-692, 1994.

Van Cappellen, P. and Ingall, E. D.: Redox stabilization of the Atmosphere and Oceans by PhosphorusLimited Marine Productivity, Science, 271, 493-496, https://doi.org/10.1126/science.271.5248.493, 1996.

van de Velde, S. and Meysman, F. J. R.: The influence of bioturbation on iron and sulphur cycling in marine sediments: a model analysis, Aquat. Geochem., 22, 469-504, https://doi.org/10.1007/s10498-016-9301-7, 2016.

van de Velde, S., Mills, B., Meysman, F. J., Lenton, T. M., and Poulton, S. W.: Early Palaeozoic ocean anoxia and global warming driven by the evolution of shallow burrowing, Nat. Commun., 9 , 2554, https://doi.org/10.1038/s41467-018-04973-4, 2018.

van de Velde, S., Hidalgo-Martinez, S., Callebaut, I., Antler, G., James, R., Leermakers, M., and Meysman, F.: Burrowing fauna mediate alternative stable states in the redox cycling of salt marsh sediments, Geochim. Cosmochim. Ac., 276, 31-49, https://doi.org/10.1016/j.gca.2020.02.021, 2020a.

van de Velde, S., James, R. K., Callebaut, I., Hidalgo-Martinez, S., and Meysman, F. J. R.: Sedimentary and plant carbon, nitrogen and phosphorus measurements of Blakeney salt marsh ponds, Marine Data Archive, https://doi.org/10.14284/419, 2020 b.

Volkenborn, N., Woodin, S. A., Wethey, D. S., and Polerecky, L.: Bioirrigation, in: Encyclopedia of Ocean Sciences, edited by: Cochran, J. K., Bokuniewicz, H. J., and Yager, P. L., Academic Press, 663-670, https://doi.org/10.1016/B978-0-12409548-9.09525-7, 2019.

Wood, R., Liu, A. G., Bowyer, F., Wilby, P. R., Dunn, F. S., Kenchington, C. G., Cuthill, J. F. H., Mitchell, E. G., and Penny, A.: Integrated records of environmental change and evolution challenge the Cambrian Explosion, Nat. Ecol. Evol., 3, 528-538, https://doi.org/10.1038/s41559-019-0821-6, 2019.

Zhao, M., Zhang, S., Tarhan, L. G., Reinhard, C. T., and Planavsky, N.: The role of calcium in regulating marine phosphorus burial and atmospheric oxygenation, Nat. Commun., 11, 2232, https://doi.org/10.1038/s41467-020-15673-3, 2020. 